\title{
O terceiro cinema em Florianópolis: duas ficções e um documentário experimentais (1968 a 1976)
}

\author{
3rd cinema in Florianópolis, Brazil: \\ two experimental fictions and one experimental documentary \\ (1968 to 1976)
}

Sissi Valente Pereira ${ }^{1}$

Resumo: Novelo (1968), A Via Crucis (1972) e Olaria (1976) são três curtasmetragens em $16 \mathrm{~mm}$, produzidos por grupos independentes em Florianópolis, SC, durante a Ditadura Militar. Neste artigo, pretendo descrever aspectos de sua composição artística, influência de movimentos internos, nacionais $\mathrm{e}$ internacionais e características estéticas que posicionam tais obras como importantes fontes de estudo do ambiente intelectual, cultural e político da cidade.

Palavras-chave: cinema experimental, Florianópolis (Santa Catarina, Brasil), ditadura militar.
Abstract: Novelo (1968), A Via Crucis (1972) and Olaria (1976) are three $16 \mathrm{~mm}$ short movies, produced by independent groups in Florianópolis (State of Santa Catarina, Brazil) during the military dictatorship. This paper describes aspects of its artistic composition, the influences of internal, national and international movements and other aesthetic features that mark these works as important sources for the study of the intellectual, cultural and political environment of the city.

Keywords: experimental cinema, Florianópolis (Santa Catarina State, Brazil), military dictatorship.

A cidade de Florianópolis é comumente representada como lugar de belezas naturais e misticismos, temas recorrentes em sua produção artística e cultural. A ponte Hercílio Luz, o mar e os barcos pesqueiros, o vento sul, as bruxas e outras lendas e a vida pacata da cidade são os principais temas elencados pela produção artística local atualmente, tendência representativa que se intensificou a partir da década de 1980. Este artigo trata de três filmes realizados em Florianópolis, entre as décadas de 1960 e 1970: os

\footnotetext{
${ }^{1}$ Mestranda em História pelo Programa de Pós-Graduação em História da Universidade Federal de Santa Catarina (ingresso em 2010). Bolsista Capes. E-mail: valente.sissi@gmail.com
} 
curtas de ficção Novelo (1968) e A Via Crucis (1972) e o documentário Olaria (1976), cujo conteúdo (formal e narrativo) difere profundamente das representações usuais da produção cinematográfica local, em que predominam os temas inspirados nas lendas e na exaltação da paisagem ilhoa. $^{2}$

Tais produções são pouco conhecidas e estão praticamente à margem da história oficial do cinema da cidade, na qual somente o filme $O$ Preço da Ilusão, ${ }^{3}$ de 1958, costuma ser citado como produção mais antiga. Este fato coincide com o caráter peculiar destes três filmes, que não exaltam e nem enquadram a paisagem de Florianópolis em panorama, muito menos tratam de lendas ou mistérios. Ao não privilegiarem os elementos que figuram nas tendências de representação acima citadas, estes filmes se distanciam deste olhar que conhecemos sobre Florianópolis e que quase se tornou um pressuposto para sua representação. Envoltos numa atmosfera sombria e angustiante, os personagens de Novelo e A Via Crucis vivem dramas existenciais e cerceamento de liberdade, em narrativas que discutem o papel do indivíduo na sociedade que se configurava com a consolidação da Ditadura Militar. Com o uso de enquadramentos fechados e cortes abruptos nas sequências de planos, a estética dos filmes parece querer

\footnotetext{
${ }^{2}$ Na coletânea de curtas-metragens lançada em 2002 e intitulada Curtas Catarinenses (volumes 1, 2 e 3) - coleção que propõe um panorama da produção de curtas-metragens da cidade -, há uma predominância bastante visível desta temática local. Os filmes Bruxas (ficção documental, 30', direção de Mauro Faccioni Filho, 1987), Farra do Boi (documentário, 25', direção de Zeca Pires e Norberto Depizzolatti, 1991), Ponte Hercílio Luz. (documentário, 30', direção de Zeca Pires, 1996), Bruxa viva (ficção, 14', direção de Lena Bastos, 1998), Ritinha (ficção, 23', direção de Antônio Celso dos Santos, 2001) e Ilha (ficção, 15', direção de Zeca Pires, 2001) representam os misticismos e tradições locais, dão enfoque à paisagem e aos costumes ilhéus e, no caso de Ritinha, representam "personagens" da cultura local, como o pescador e a rendeira. O filme Alma açoriana (documentário-ficção, 45', direção de Penna Filho, 2001), que não está presente na Coleção Curtas Catarinenses, também é um exemplo da utilização desta temática, ao explorar a cultura de base açoriana, com ênfase nos costumes, lendas e tradições locais.

${ }^{3}$ Lançado em 1958, o filme $O$ Preço da Ilusão é o primeiro longa-metragem realizado em Florianópolis. Idealizado e produzido pelo Círculo de Arte Moderna (mais conhecido como Grupo Sul), o filme foi exibido somente em sua estreia, apresentando problemas de dessincronia entre áudio e imagem, que provocaram duras críticas à obra. Com a representação de duas histórias paralelas: a da moça que queria ascender socialmente por meio de um concurso de miss e a do garoto pobre que queria montar um boi-de-mamão e arrecadar dinheiro para os remédios de sua mãe, o filme também queria valorizar a paisagem ilhoa, sua cultura, seus costumes e seu cotidiano. Produzido por Armando S. Carreirão, dirigido por Nilton Nascimento e com argumento criado por Eglê Malheiros e Salim Miguel, o filme desapareceu logo após a sua estreia. Hoje só existem o roteiro original e os sete minutos finais, preservados no Museu da Imagem e do Som de Santa Catarina.
} 
complementar uma atmosfera de prisão também sugerida nas narrativas. Por sua vez, o documentário Olaria, ao dar 'voz' ao oleiro (contra a perspectiva do documentário sociológico), denuncia o fim iminente das olarias de São José (cidade contígua a Florianópolis), diante do crescente processo de industrialização. Pretendo aqui elencar e discutir alguns aspectos da constituição formal e estética destes filmes, que os alinham a uma perspectiva de cinema político de vanguarda. Considero importante este resgate, já que os movimentos de vanguarda foram comumente marginalizados em seus contextos de ação e, no caso da história do cinema de Florianópolis, mergulharam profundamente no esquecimento. Podemos, por fim, listar outros fatores que situam a importância do estudo destes filmes: sua realização em um período de repressão política; o caráter amador de sua produção e seu pioneirismo, por serem os primeiros curtasmetragens produzidos na cidade de Florianópolis; os temas abordados, ousados para um ambiente de ditadura, que discutem questões como condições de trabalho, censura, repressão política, sexualidade e existencialismo; a experimentação no uso dos procedimentos narrativos, que tem correspondências com correntes de cinema de vanguarda; o olhar peculiar sobre a cidade de Florianópolis, que a mostra sob ângulos fechados, sem privilegiar os detalhes e o panorama das paisagens que comumente são retratadas de maneira explícita em outras obras fílmicas locais mais recentes.

O filme experimental, ao negar um modelo hegemônico de cinema, pretende produzir uma reflexão sobre a realidade que o cerca, por meio de uma revolução formal, na qual são ressignificados os usos do aparato técnico. A partir do início do século XX, os movimentos vanguardistas no cinema agiram de forma a evidenciar os elementos do discurso cinematográfico, com o objetivo de "desrealizar" a imagem e dotá-la de intencionalidades. ${ }^{4}$ Desta forma, o cinema naturalista, ${ }^{5}$ de mensagem óbvia e plena de sentido, foi sendo contestado pelas vanguardas, por meio do uso experimental dos procedimentos narrativos. O cinema de vanguarda incorporou o discurso sobre suas condições materiais de produção e se voltou contra a grande indústria em favor de seu estatuto como obra de arte ou como peça revolucionária. Ismail Xavier propõe dois conceitos para se

\footnotetext{
${ }^{4}$ O cinema construtivista russo, o cinema expressionista alemão e o surrealismo são exemplos destes movimentos, que foram instituídos por volta das décadas de 1920 e 1930 .

${ }^{5} \mathrm{O}$ cinema naturalista é aquele que se utiliza da chamada decupagem clássica, modelo de montagem que simula uma naturalidade para os acontecimentos representados, sem que estes sejam percebidos pelo espectador como uma manipulação do editor. Este modelo foi institucionalizado pelo cinema hollywoodiano clássico.
} 
discutir esta oposição entre o cinema de vanguarda e o modelo de cinema hegemônico: a opacidade e a transparência da linguagem cinematográfica. O conceito de transparência refere-se ao modelo naturalista, que neutraliza a montagem com o intuito de representar o "real" e esconder o discurso cinematográfico. O conceito de opacidade refere-se ao cinema de vanguarda:

O cinema revolucionário, ao destruir a ideia de representação, ao se negar a fornecer a imagem transparente, produz um conhecimento sobre ele mesmo, em primeiro lugar, como condição para a produção de um conhecimento dirigido a uma realidade que engloba o filme. $\mathrm{O}$ essencial na nova proposta é desrealizar a imagem, evidenciá-la como peça de discurso; é deconstruir [sic] o sistema de regras da narração e da decupagem-montagem próprias ao cinema burguês. À mistificação da janela que se abre para o real (dado natural), é preciso responder com a materialidade da imagem/som como signo produzido, e com o cinema-discurso. ${ }^{6}$

O cinema "transparente" é aquele que prioriza a narração, esconde a técnica cinematográfica (acentuando a continuidade dos planos) e, por isso, é mais facilmente entendido; possui uma linearidade característica do romance clássico. O cinema "opaco" é aquele que evidencia a experimentação dos elementos formais em busca da produção de significados não aparentes, por meio das imagens. Difere do cinema transparente, pois nega a linearidade como pressuposto para a representação e se utiliza dos elementos formais de formas diversas, não necessariamente inteligíveis à maneira clássica. O principal ponto de divergência entre estas duas tendências é a mudança no estatuto da imagem filmada: para o cinema "opaco", a imagem não é uma expressão pura da realidade, como se esta fosse somente transplantada para a tela do cinema, mas sim uma manipulação dos elementos componentes do filme; os enquadramentos utilizados, o tipo de iluminação e a cena representada, são escolhas direcionadas e dotadas de intencionalidades. Para as vanguardas, os elementos formais característicos das diferentes técnicas artísticas passaram a ser a única coisa palpável, portanto, o único real a ser trabalhado. $\mathrm{O}$

\footnotetext{
${ }^{6}$ XAVIER, Ismail. O discurso cinematográfico: a opacidade e a transparência. Rio de Janeiro: Paz e Terra, 1977. p.134.
} 
pincel, a tinta e o suporte, na pintura; a câmera, a luz, a película, o corte, o enquadramento, no cinema. Ciente desta intencionalidade, o cinema clássico a utilizava sem assumi-la, enquanto que as vanguardas, ao elaborarem de outra forma sua relação com a representação, assumiram o filme como discurso e suas condições técnicas como as ferramentas de uma linguagem.

Novelo, A Via Crucis e Olaria são três obras de curta-metragem que dialogam com os chamados Novos Cinemas, movimentos vanguardistas que, a partir da década de 1950, reelaboraram suas concepções acerca da função social do filme. O Neorrealismo italiano, a Nouvelle Vague francesa, o Cinema Novo alemão e os diversos movimentos na América Latina, pertencentes ao chamado Novo Cinema Latino-Americano, são exemplos de propostas no campo cinematográfico que atribuíram novos usos e significados à estrutura formal e estética, para propor um cinema reflexivo, crítico e político. Influenciados pelo Neorrealismo italiano, os movimentos do Novo Cinema Latino-Americano surgiram por volta da década de 1950. O conceito de Terceiro Cinema, primeiramente citado em manifesto dos cineastas argentinos Fernando Solanas e Octavio Getino, em 1968 (intitulado Hacia un Tercer Cine $^{7}$ ), se refere ao cinema latino-americano, numa alusão à denominação de Terceiro Mundo, atribuída aos países subdesenvolvidos ou em desenvolvimento. O Terceiro Cinema seria o cinema revolucionário dos países de Terceiro Mundo, que discutiriam, em suas obras, temas relacionados às suas condições de dependência econômica e política. Este termo tornou-se uma comum referência ao cinema latinoamericano do período, no qual se inserem o Cinema Novo brasileiro, o cinema argentino, boliviano, chileno, cubano, mexicano, entre outros. ${ }^{8}$ No Terceiro Cinema, a discussão dos problemas sociais e políticos dos países de Terceiro Mundo é realizada a partir de uma estética que reivindica para si a condição de cinema subdesenvolvido. Os manifestos publicados na época, pelos cineastas Glauber Rocha (Por uma estética da fome), Fernando Birri (Cine e subdesarrollo), Júlio Garcia Espinosa (Por um cine imperfecto) e Fernando Solanas e Octavio Getino (Hacia un Tercer Cine), são textos que defendem uma estética "suja", mal acabada, fruto das más condições técnicas e da falta de incentivo financeiro inerentes ao cinema latino-

\footnotetext{
${ }^{7}$ SOLANAS, Fernando; GETINO, Octavio. Toward a third cinema. In: MARTIN, Michael T. (Org.) New Latin American Cinema: Theory, practices, and transcontinental articulations. Detroit: Wayne State University Press, 1997. v.1. p. 37.

${ }^{8}$ Para maiores informações sobre o Terceiro Cinema e os cineastas latino-americanos, ver: CAETANO, Maria do Rosário. Cineastas latino-americanos: entrevistas e filmes. São Paulo: Estação Liberdade, 1997; AVELLAR, José Carlos de. A ponte clandestina: teorias de cinema na América Latina. São Paulo: Edusp, Editora 34, 1996.
} 
americano. Esta "estética da fome" seria a expressão legítima de um cinema que não quer esconder sua miséria, mas sim, problematizá-la.

A aproximação dos curtas-metragens aqui elencados com o Novo Cinema Latino-Americano se dá principalmente pelas questões políticas, filosóficas e ideológicas que abordam. De caráter experimental, baixo orçamento e produção amadora, os três filmes discutem a intensificação das relações capitalistas, a repressão política da Ditadura Militar e o falecimento dos ideais de sociedade almejados antes do golpe civil-militar de 1964. A radicalidade presente em sua estética e a falta de refinamento técnico denotam uma atitude de urgência, característica de uma arte engajada.

\section{Florianópolis: as artes no pós-guerra e o contexto de realização de Novelo, A Via Crucis e Olaria.}

A despeito de o movimento modernista nacional ter surgido ainda na década de 1920, em Florianópolis ele só iria se manifestar, ao menos como movimento organizado, no pós-Segunda Guerra. No cenário artístico, a cidade começa a ter "ares modernos" com o Círculo de Arte Moderna (mais conhecido como Grupo Sul), fundado em 1947 e composto por poetas, artistas, literatos e intelectuais que agitaram a pacata capital. O grupo encenou peças de teatro (Sartre, Pirandello e Bernard Shaw) e editou por dez anos a Revista Sul, um importante periódico literário local. A revista teve como principal característica o intercâmbio com artistas de vários países da Europa e da América Latina. Nela eram publicados poemas, contos e desenhos de artistas estrangeiros, numa troca de informações impressionante para os limites da cidade. Foram também lançados pelo grupo os Cadernos Sul e as Edições Sul, publicações de obras de diversos autores catarinenses. A criação do cineclube do Círculo de Arte Moderna e a realização do primeiro longa-metragem da cidade, o filme O Preço da Ilusão, em 1958, foram as propostas do grupo no campo cinematográfico.

Nas décadas de 1960 e 1970, a pacata Florianópolis, pouco atuante no cenário nacional, sem uma economia forte e com pequeno crescimento populacional, passava por transformações. A fundação da Universidade Federal de Santa Catarina - UFSC, em 1960, a transferência da sede da Eletrosul para a capital em 1970 e a implantação da BR 101 (inaugurada em 1971, no governo Colombo Salles), ligando a capital às demais cidades do Estado, foram transformações estruturais que, além de promoverem súbito aumento populacional, desencadearam o processo de especulação imobiliária, hoje bastante intensificado. $\mathrm{O}$ aterro da baía sul e a construção 
da ponte Colombo Salles (inaugurada em 1975), estabelecendo mais uma ligação da Ilha de Santa Catarina com o continente, também foram intervenções que modificaram profundamente a dinâmica da cidade, afastando o mar do centro e retirando-o da convivência diária com os moradores, moldando assim, um estereótipo de cidade grande para Florianópolis.

Nas artes plásticas, uma nova geração de artistas alçou voos um pouco mais altos e ousados, em relação aos seus antecedentes. O abandono da pintura figurativa se mostrou cada vez mais presente, em parte sob a influência de Silvio Pléticos, pintor iugoslavo que chega a Florianópolis na metade da década de 1960. Pléticos influenciou certo grupo de artistas locais, que abandonaram o figurativo como pressuposto para a representação. Em 1969 foi fundado o Grupo Noss'Arte, formado por artistas com tendências surrealistas e abstratas, alunos de Pléticos. No mesmo período, Hassis (Hiedy de Assis Corrêa) também propôs mudanças representativas em sua obra, com a série de colagens intitulada ONTENMANHÃ.$^{9}$ O Grupo Noss'Arte, formado principalmente por Jayro Schmidt, Max Moura e João Otávio Neves (mais conhecido como Janga), ${ }^{10}$ levou exposições de suas obras aos morros, ruas e escolas da cidade, com o objetivo de aproximar a arte do público, tirando-a dos espaços de exposição tradicionais. Foi um período de renovação estética na capital, cujos artistas, diante da impossibilidade de se expressarem politicamente, buscaram fazêlo por meio das artes, experimentando novos conceitos e técnicas. No cinema não foi diferente. Em 1962, ex-integrantes do Grupo Sul organizaram a $1^{a}$ Semana do Cinema Novo Brasileiro, com a participação de Paulo Emílio Sales Gomes (via rádio), com intenção de discutir a nova estética:

Nesta semana, além da apresentação dos cinco longas-
metragens (Senhor dos Navegantes, de Aluísio T. de
Carvalho; Nordeste sangrento, de Wilson Silva; A Ilha,
de Walter Hugo Khoury; A grandefFeira e Cinco vezes
favela) e de alguns curtas, aconteceram debates com os
associados do Clube de Cinema de Florianópolis, com
o tema "O Chamado Cinema Novo". São também
realizadas mesas redondas pelo rádio com a

\footnotetext{
${ }^{9}$ A série ONTENMANHÃ é composta por colagens (com o material de revistas e jornais sobre tela) e pequenos filmes experimentais em superoito.

${ }^{10}$ Também participaram do grupo Elbe Duarte Araújo, Flávio Moritz, José Pedro Heil, Luís Si, Maria Goretti Heil, Semy Braga e Vera Sabino.
} 
participação de críticos como Paulo Emílio Sales Gomes, Salvino Cavalcanti de Paiva, P. F. Gastal, Cláudio Abramo e outros." 11

Novelo, A Via Crucis e Olaria são filmes que condensam muito da visão política de seus realizadores, visão esta presente em suas trajetórias pessoais, como intelectuais e artistas. Pedro Bertolino, autor dos argumentos de Novelo e de A Via Crucis, já era na época professor de filosofia, além de crítico literário, poeta concretista (participava dos movimentos de poema concreto e processo, em São Paulo e no Rio de Janeiro) e estudioso do existencialismo de Jean Paul Sartre. Gilberto Gerlach, fotógrafo e codiretor de Novelo, era estudante de engenharia civil, fotógrafo profissional, cinéfilo, crítico de cinema e grande articulador do cineclubismo em Florianópolis; Gerlach havia fundado, no mesmo ano da realização do filme, o cineclube Nossa Senhora do Desterro, ${ }^{12}$ que ainda se encontra em funcionamento. Pedro Paulo de Souza, diretor e roteirista de Novelo, era estudante de administração e grande apreciador de cinema e ópera. Ady Vieira Filho, produtor e ator coadjuvante de Novelo, era estudante de contabilidade, militante estudantil e membro do Partido Comunista; Ady Vieira havia fundado, no mesmo ano da realização de Novelo, a galeria Mini Mercado de Artes, que reuniu jovens artistas plásticos da cidade, adeptos da pintura abstrata. Orivaldo dos Santos, que participou somente da elaboração do roteiro de Novelo, era cinéfilo e crítico de cinema. Nelson dos Santos Machado, diretor e fotógrafo de A Via Crucis e Olaria, era na época estudante de sociologia (tornou-se professor da UFSC, hoje aposentado), fotógrafo profissional e artista plástico. ${ }^{13}$

\footnotetext{
${ }^{11}$ PIRES, José Henrique Nunes; DEPIZOLATTI, Norberto Verani; ARAÚJO, Sandra Mara de. O Cinema em Santa Catarina. Florianópolis: UFSC, 1987. p. 53.

${ }^{12} \mathrm{O}$ cineclube foi fundado em 1968, com o nome de Cineclube da Engenharia. Passou a se chamar Nossa Senhora do Desterro em 1972, data de sua oficialização junto à Embrafilme. O cineclube funciona até hoje, no Centro Integrado de Cultura (CIC), em Florianópolis.

${ }^{13}$ Entre os anos de 2003 e 2005, o grupo de pesquisa que se reunia no Laboratório de Pesquisa em Imagem e Som - LAPIS, da UFSC, e do qual eu fazia parte, entrevistou cinco integrantes do grupo que realizou Novelo; só não foi entrevistado o ator Fernando José da Silva. As entrevistas são a principal fonte utilizada para recuperar detalhes do processo de concepção e de realização do filme. Nelson dos Santos Machado também é o único realizador de A Via Crucis e Olaria com quem conversamos durante a realização das entrevistas. Segundo seu depoimento, foram ele e sua esposa na época, Deborah Cardoso Duarte, os mentores dos dois filmes e que participaram de todas as etapas de realização, da direção à montagem.
} 
O objetivo desta pequena exposição de datas e eventos é o de sintetizar o ambiente intelectual da cidade nas décadas de 1960 e 1970. Estes grupos de artistas, ao "fugirem" da tradição figurativa nas artes plásticas, do poema parnasiano e da estética do cinema clássico hollywoodiano, demonstram uma inquietude e um desassossego que, durante estes anos de Ditadura Militar, teriam semelhanças com os diversos movimentos nas artes de vanguarda do mundo todo.

Impulsionados pela descoberta inesperada de um acervo de câmeras e projetores abandonados num depósito da UFSC, ${ }^{14}$ o grupo de estudantes, que adotou para si o nome de GUCA (Grupo Universitário de Cinema Amador), pediu autorização à reitoria para utilizar o material, e decidiu fazer cinema. O primeiro filme a ser rodado foi Novelo (em 1968), com o objetivo de participar do $4^{o}$ Festival de Cinema Amador Jornal do Brasil/Mesbla, no Rio de Janeiro. O filme ganhou menção honrosa no festival. A Via Crucis e Olaria foram realizados com a utilização do mesmo material, só que por outro grupo, formado por integrantes do Diretório Central dos Estudantes da UFSC e encabeçado por Nelson dos Santos Machado e Deborah Cardoso Duarte. Olaria participou da V Jornada Brasileira de Curta Metragem, em 1976, em Salvador.

\section{Narrativa de Novelo}

O filme Novelo, de 1968, formato $16 \mathrm{~mm}$, tem duração de 16 minutos. ${ }^{15} \mathrm{O}$ primeiro curta-metragem de ficção realizado em Florianópolis é um filme hermético na utilização dos procedimentos narrativos. Sem diálogos, é composto por cenas sem significado claro, com enquadramentos de câmera fechados, que mostram instantes do cotidiano do protagonista. A trilha sonora é de música erudita: Igor Stravinsky, Francisco Mignone e Heitor Villa-Lobos.

O filme, já na apresentação dos créditos, provoca certo estranhamento com os títulos intercalados a cenas disformes e fora de foco,

\footnotetext{
${ }^{14}$ As câmeras e projetores foram enviados à UFSC, a partir de um intercâmbio com uma universidade da Alemanha Oriental antes do golpe civil-militar de 1964. Ainda é obscura a origem deste material, pois a documentação de sua procedência não foi localizada. Portanto, estas informações foram adquiridas somente a partir dos depoimentos dos realizadores dos filmes.

${ }^{15}$ O filme foi realizado por Pedro Paulo de Souza, responsável pela direção, roteiro e sonoplastia, Pedro Bertolino, autor do argumento, Ady Vieira Filho, produtor e ator, Fernando da Silva, ator, e Gilberto Gerlach, fotógrafo e codiretor.
} 
que logo se tornam imagem de fetos e espermatozóides de uma série de quadros do pintor Hiedy de Assis Correa. ${ }^{16}$ A representação de fetos instaura um clima sombrio no filme. No início, vemos o personagem, em sua biblioteca, lendo uma frase em um livro de Martin Heidegger: ${ }^{17}$ "Os valores não são, eles valem..." Após a leitura da frase, ele se levanta, retira da estante de livros a Bíblia e a joga no lixo. Surge a imagem da Catedral de Florianópolis desestruturada, como se estivesse desmoronando (por um efeito de filmagem). O protagonista atravessa um corredor bastante iluminado e de paredes brancas (a câmera é fixa e está localizada no chão, filmando-o da cintura para baixo, de costas). Uma gilete se aproxima de seu pescoço movendo-se sozinha, numa cena de grande tensão sugerida pelo close na gilete, que parece flutuar. Ele surge deitado na cama, de olhar distante e aparência angustiada. Observa, pendurada na parede, a pintura de uma mulher, cuja imagem é intercalada à de um bebê sendo retirado da lama (representado por um boneco de plástico). Da janela de seu quarto, o protagonista contempla a paisagem, quando subitamente pega a chave do carro e sai. De carro, ele sai de casa em direção à ponte Hercílio Luz (de dentro do carro, a câmera o filma de costas, num plano fechado, onde aparecem sua nuca e o volante). Ao chegar à ponte, o carro para em um engarrafamento (a ponte não é mostrada em panorama, mas também sob planos fechados, que enfocam sua estrutura metálica sem definir sua forma amplamente conhecida). ${ }^{18}$

Ao chegar ao centro da cidade, o protagonista passeia desinteressado, por entre as pessoas (neste momento o áudio é de uma grande avenida de São Paulo e foi gravado durante a montagem do filme). As cenas são ligeiramente caóticas, efeito provocado pela filmagem em planos fechados, que sugere um ambiente abarrotado e confuso: pessoas passam entre a câmera e o personagem e há muita interferência de árvores e carros. Surge a imagem de um muro branco, pichado com a frase: "Nosso

\footnotetext{
${ }^{16}$ Conhecido como Hassis, Hiedy de Assis Correa foi desenhista, pintor e autodidata. Atuou como artista plástico em Florianópolis a partir do final da década de 1940 até falecer, em 2000 .

${ }^{17} \mathrm{~A}$ frase está presente no livro Introdução à Metafísica, de Martin Heidegger: HEIDEGGER, Martin. Introdução à Metafísica. Rio de Janeiro: Tempo Brasileiro, 1999. p.16.

${ }^{18}$ Nas fotografias da época era comum a representação da ponte Hercílio Luz vista de sua cabeceira, detalhe bastante incomum atualmente. Sua posição como única ligação rodoviária da ilha ao continente lhe conferia esta função de via de acesso. Hoje sua figura existe somente como monumento, fato que institucionalizou sua representação em panorama.
} 
protesto não morreu". ${ }^{19}$ Em frente ao muro há um mendigo sentado, que recebe esmola de um transeunte. Em outro ponto do centro, o protagonista é representado de cima e olha para os lados, como se quisesse reconhecer alguém, no meio da multidão. Ele parece desistir e sai de carro novamente. Num ambiente mais arejado e deserto (um antigo cais, no centro da cidade), o personagem principal encontra um homem, com quem trava uma conversa tensa (com muitos cortes na sequência, sugerindo uma atitude de urgência). $\mathrm{O}$ protagonista mostra-se fechado e taciturno, contrariamente à atitude do outro, de roupas claras e gestos amplos. $\mathrm{O}$ segundo parece querer convencêlo de algo, mas não consegue. Dali, o protagonista segue de carro por uma estrada rústica até chegar à praia, onde, ao sair do carro, abandona no chão a chave, sem trancá-lo. Ele aparece em outra cena contemplando o mar (os planos agora são mais abertos, mostrando o horizonte e o mar). Há uma pequena sucessão de planos que mostram seu rosto em close, olhando para o mar, com uma expressão séria e melancólica. Surge a imagem de preservativos usados e pílulas anticoncepcionais na grama, tomados por formigas. Ele aparece nu à beira-mar, em meio às pedras, em posição fetal. Sucedem-se vários planos diferentes do personagem na mesma posição, mas em lugares diversos da praia. A imagem perde o foco aos poucos. FIM.
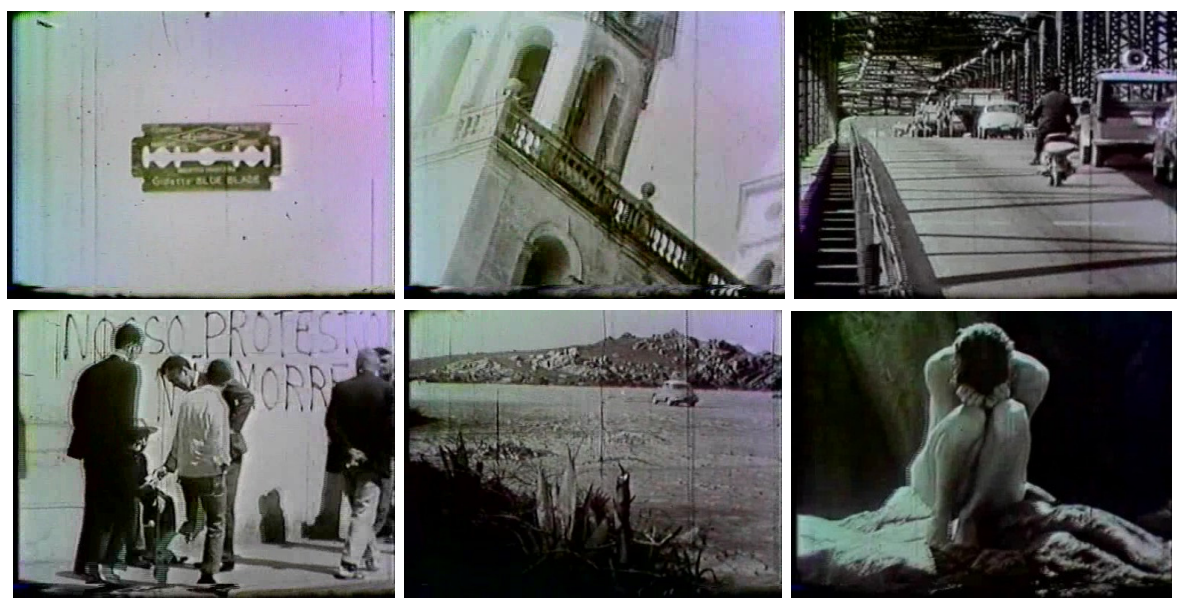

Cenas de Novelo: a gilete; a catedral desmoronando; a ponte Hercílio Luz filmada de seu interior; no centro da cidade, o muro com a pichação "Nosso Protesto Não Morreu"; na praia, plano aberto; a cena final.

${ }^{19}$ De acordo com as entrevistas com os realizadores, a frase havia sido pichada na noite anterior, e o grupo, ao realizar as cenas no dia seguinte, descobriu a pichação e resolveu filmar o muro, com o objetivo de registrar o protesto. Logo o muro foi pintado de branco novamente. 


\section{Narrativa de $A$ Via Crucis}

O filme A Via Crucis, de 1972, no formato 16mm, tem duração de 10 minutos. ${ }^{20}$ A Via Crucis também é um curta-metragem de características herméticas em sua narrativa. Em seu enredo obscuro, é dada maior ênfase à justaposição de planos, que compõem um conjunto de significações talvez mais subjetivo que em Novelo. $\mathrm{O}$ filme faz uma alusão à tragédia bíblica, encenando a crucificação do indivíduo moderno, com a representação dos episódios da Via Crucis. Intituladas já nos créditos iniciais do filme, as Estações da encenação representadas são: Condenação, Caminho da Cruz, Queda, Encontro, Flagelação e Morte.

O filme tem início com uma imagem panorâmica do centro da cidade de Florianópolis, visto de um trapiche. Na cena seguinte, uma rua movimentada, com muito trânsito de pessoas (a cena é escura devido ao uso de contraluz; a não identificação da fisionomia dos personagens nas cenas de contraluz é bem presente em todo o filme). Em seguida, o protagonista aparece de costas e várias mãos lhe apontam o dedo indicador (ênfase nos dedos com closes).

Surge, em seguida, uma sucessão de planos com imagens que sugerem enclausuramento: um rato em uma jaula, crianças brincando atrás das grades de um parque e um ônibus em movimento com os passageiros vistos pelas janelas. Seguem-se cenas de operários em uma construção: homens com enxadas, cenas de esforço físico, pés descalços cavando na lama (são mostrados sem características individuais: seus rostos não aparecem, são vistos por planos fechados, que cortam detalhes das cenas para mostrá-las de maneira genérica). O protagonista sobe escadas em direção a uma grande porta (da Catedral de Florianópolis), enquanto esta se fecha em sua frente, antes que ele consiga alcançá-la.

Uma mulher corre pelo lado de fora de um grande prédio, em tentativas frustradas de abrir suas várias portas, num ritmo desesperado (sugerido pelos movimentos da câmera, bruscos e agitados, que simulam às vezes o seu olhar). Na sequência seguinte, vemos a mesma mulher, agachada e cabisbaixa. Ela aparece filmada de cima, enquanto a câmera

20 O filme foi realizado por Nelson dos Santos Machado e Deborah Cardoso Duarte, que assinam a direção e fotografia. José Henrique Moreira, Álvaro Reinaldo de Souza, Ester Brattig, Marcus Brattig, Olinda Machado, Vera Collaço, Nei Gonçalves e Yara Koneski Abreu, membros do Diretório Central dos Estudantes da UFSC, participaram como atores da ficção. Pedro Bertolino foi o autor do argumento. 
distancia-se e sua figura se torna um pequeno ponto, na tela quase vazia. Um homem aparece de carro e abre a porta para ela, que levanta a cabeça. Seguem-se mais cenas de construção com máquinas e homens trabalhando.

O protagonista encontra duas mulheres, aproxima-se delas e as duas lavam seu rosto. Na praia, ele e uma mulher (da cena anterior) dão risadas e se dão as mãos. Alguns homens de terno e gravata aparecem, cortam os cabelos do protagonista e rasgam sua camisa. Segue a cena de um apito de fábrica tocando. Surge o rosto de um senhor de olhar curioso, ofuscado pelo sol e com dedos na boca. A unha do personagem é arrancada. Uma mulher idosa dá gargalhadas. Um motorista dentro de seu carro buzina freneticamente. Aparece uma sirene de um carro de polícia e seu som se mistura a barulho de multidão. Uma mulher idosa olha para a câmera com desdém. A confusão das cenas anteriores (aliada à musica perturbadora e inconstante do compositor alemão Karlheinz Stockhausen) é substituída pelo silêncio. O protagonista surge deitado no asfalto, vestindo somente uma tanga branca, de braços abertos (em uma alusão à posição de Jesus Cristo na cruz). A imagem da cidade reaparece e se repete sob diversos ângulos. FIM.
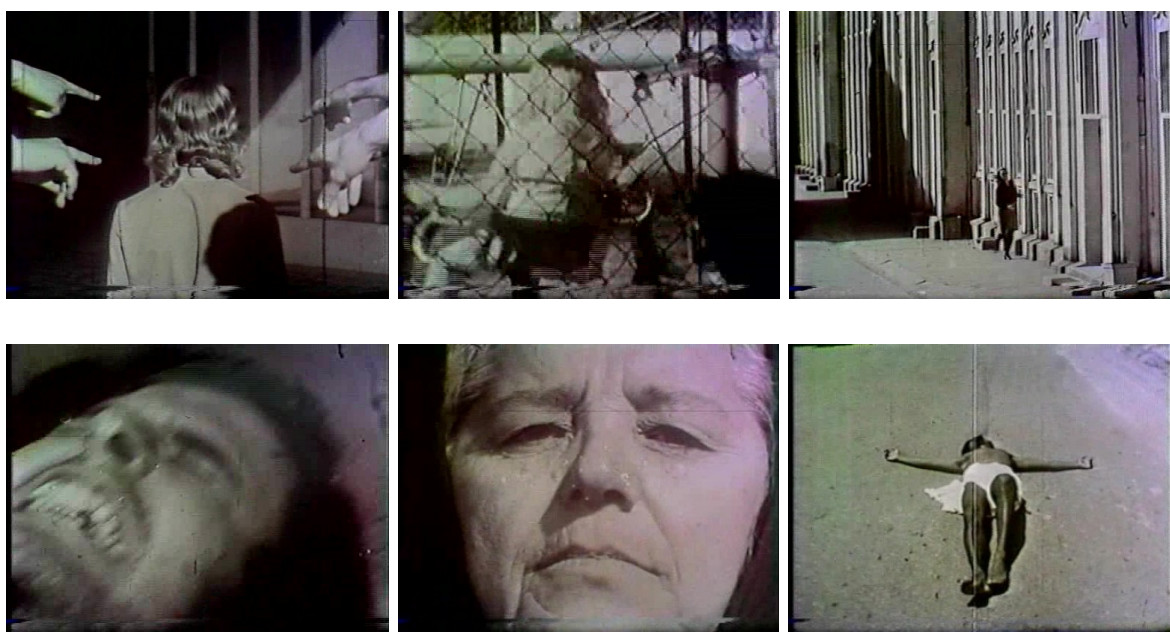

Cenas de A Via Crucis: A condenação do personagem; as crianças no parque com grades; cena das portas fechadas; a tortura; senhora com olhar reprovador; o protagonista crucificado no asfalto. 


\section{Narrativa de Olaria}

O filme Olaria, de 1976, formato $16 \mathrm{~mm}$, tem duração de 10 minutos. $^{21}$ Olaria, ao contrário dos outros curtas de ficção, é um documentário que fala das olarias da Ponta de Baixo, em São José, cidade contígua a Florianópolis. O filme molda sua narrativa a partir do depoimento do Sr. Ricardo, dono de uma das três olarias que na época haviam sobrado, das treze anteriormente existentes, segundo o relato presente no filme. A fala do Sr. Ricardo não foi sincronizada com as imagens de seu depoimento. Ela é apresentada como uma narração do documentário e relata o processo de desaparecimento das olarias devido ao aumento do custo de vida (provocado pelo crescimento da cidade, aumento do imposto territorial) e da concorrência com produtos industrializados. Ele conta como criou seus nove filhos com o fruto de seu trabalho na olaria; que todos os nomes de seus filhos iniciam-se com a letra "o"; que todos estudaram e que estão em melhores condições do que se tivessem seguido o ofício do pai. As imagens, por sua vez, mostram todo o processo de manufatura dos artefatos de barro, desde a retirada da argila, até tomarem sua forma final.
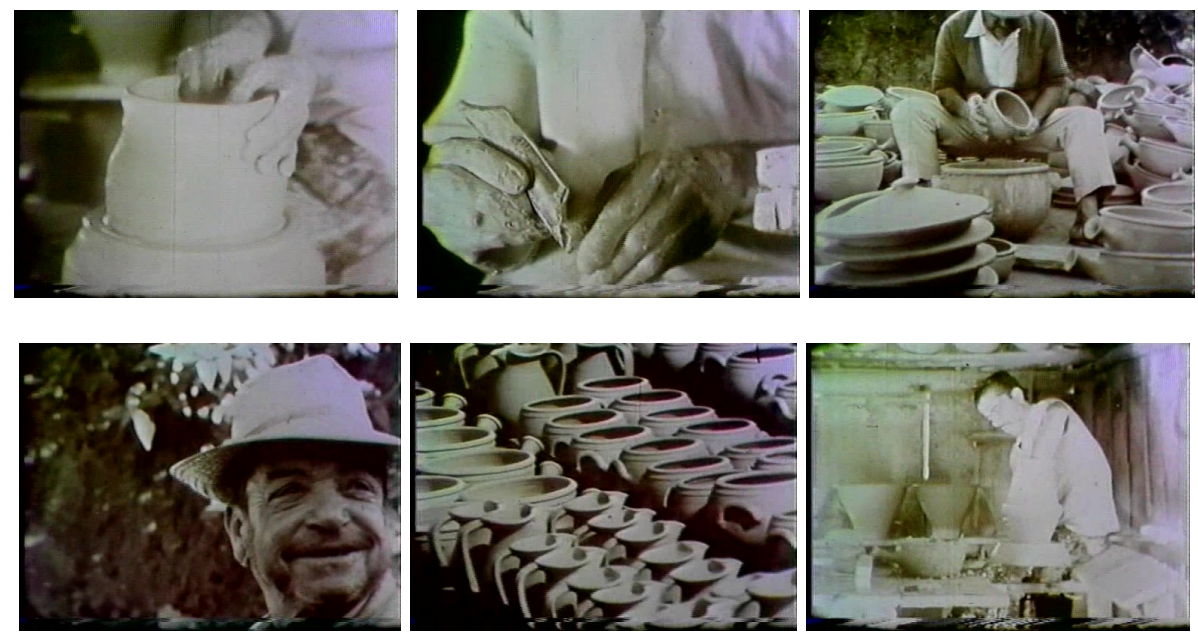

Cenas de Olaria: os planos mais fechados, com detalhes do trabalho; a imagem do Sr. Ricardo.

${ }^{21} \mathrm{O}$ documentário foi realizado por Nelson dos Santos Machado e Deborah Cardoso Duarte, que assinam a direção, fotografia e argumento. O roteiro foi concebido em parceria com José Henrique Moreira e Iracema Moreira, membros do Diretório Central dos Estudantes da Universidade Federal de Santa Catarina, e a sonoplastia por Deborah Cardoso e Iracema Moreira. 


\section{Morte e desilusão: Novelo, A Via Crucis e Olaria}

\section{Novelo}

O filme Novelo foi concebido sem diálogos, devido à falta de equipamentos de captação de áudio e devido à possibilidade de o filme sofrer cortes antes de sua exibição, no IV Festival do Jornal do Brasil/Mesbla, já que se tratava do ano de 1968. Estes fatores deram ao filme um caráter essencialmente visual.

Em Novelo o espectador deve extrair da montagem e da narrativa um conjunto de significações expresso de forma cifrada. A leitura da frase "Os valores não são, eles valem..." desencadeia no protagonista um processo que vai da angústia à desapropriação material e simbólica de elementos presentes em seu cotidiano, que o configuram como um indivíduo moderno. Se os valores não são, mas somente valem, sua validade é determinada pelo contexto histórico, pela cultura e pelo poder dominante, dado que provoca, por parte do personagem, a contestação da própria estrutura social, como está configurada em fins da década de 1960. Algumas das ideias transmitidas pelo filme representam os valores negados pelo protagonista: a falência da religião, representada pelo "desmoronamento" da catedral; a negação da família e do nascimento, com a junção da imagem de uma mulher à de um bebê sendo retirado da lama; a ideia de suicídio iminente ou morte involuntária, na cena de grande tensão provocada pela gilete, que se aproxima lentamente de seu pescoço; o rompimento com a civilização e o ambiente urbano, nas cenas caóticas do centro da cidade; a fuga para o mar e a destituição de valores materiais, com o abandono da chave do carro e das roupas; e a posição fetal e a nudez, que podem simbolizar uma volta ao útero, uma busca pelo sentimento de proteção perdido. A influência do existencialismo de Jean Paul Sartre (presente já na intenção do argumento) envolve a narrativa e justifica a conduta do personagem: a angústia diante da responsabilidade sobre suas ações o faz decidir a negar a sociedade e sua configuração. Sua atitude representa uma revolta simbólica, individual, de privação, e carrega consigo um ideal de sociedade diferente, representando assim, um sentimento coletivo cultivado na época. Pedro Bertolino, autor do argumento de Novelo, comenta a escolha da cena final, que sugere um suicídio:

[...] o propósito era passar a ideia de um despojamento para o renascimento da civilização, já que não havia outro caminho além do despojamento e o renascimento para outras formas de vida, porque a luta era 
impossível. Você vê ali aquela sequência da esmola, criticando exatamente o assistencialismo, Aliança para o Progresso, tudo aquilo militarizado. Mas você vê lá no muro: Nosso protesto [não morreu] era o máximo que era possível se dizer na época. A saída era somente essa: o despojamento das pessoas com a civilização, sair dessa civilização e o renascer para outra. ${ }^{22}$

Entre os principais elementos de linguagem utilizados em Novelo estão os planos fechados, que, além de limitar a visão das cenas, possuem a interferência dos personagens, que parecem não se apresentar diretamente ao espectador. A câmera por vezes é obstruída pela sua presença, indicando certo distanciamento do protagonista em relação ao espectador e, consequentemente, em relação ao mundo. Conceitualmente ele quer se destituir dos valores sociais, e se distancia da sociedade, do mundo, não só intencionalmente, por meio da simbologia dos seus atos, mas também e principalmente por meio de sua postura diante da câmera. $\mathrm{O}$ mundo que é mostrado no filme, representado pelo ambiente urbano, parece distante do protagonista e ele aparece sempre deslocado dentro deste ambiente social. $\mathrm{O}$ centro da cidade, a ponte, o movimento intenso dos carros e dos habitantes, se mostram completamente alheios a ele e a agitação destas cenas contrasta fortemente com sua apatia e seu semblante melancólico.

A acentuação dos planos fechados aparece principalmente quando o filme estabelece a relação do personagem com as questões que ele se propõe a negar: no ambiente urbano, no centro da cidade; quando ele se depara com a imagem da gilete; quando confronta, calado, as tentativas de convencimento de seu amigo. A montagem e os enquadramentos do filme atribuem significado às cenas: enquanto o protagonista permanece taciturno, os planos são fechados. Quando o personagem chega à praia, o carro já surge em um plano aberto, quase panorâmico. Nas cenas à beira-mar, a angústia antes explícita na expressão do protagonista parece se dissipar e os planos mais abertos nos transmitem uma tranquilidade antes não encontrada na cidade. A praia representa, assim, uma fuga do ambiente urbano, sufocador, símbolo das mazelas por que passa o personagem. Os cortes secos são responsáveis por acentuar as significações das cenas, a partir da justaposição entre dois planos, sem transições, além de atribuírem certa

22 BERTOLINO, Pedro. Depoimento, dezembro de 2004, Santa Mônica, Florianópolis. Entrevistadores: Gláucia Dias da Costa e Henrique Pereira Oliveira. Acervo do Laboratório de Pesquisa em Imagem e Som - LAPIS, UFSC. 
rigidez à montagem, contribuindo com a seriedade que o filme quer transmitir.

No filme há momentos em que o recurso da imagem fora de foco é intencionalmente utilizado: na cena em que a gilete aparece pela primeira vez, sozinha no meio do plano; quando o protagonista deita-se na cama antes de observar o retrato da mulher na parede; no início da sequência da conversa entre os dois personagens, no cais; no final do filme, quando o protagonista está em posição fetal. Este recurso proporciona certo estranhamento por parte do espectador, diante da imagem que não se define claramente. No início do filme, após o protagonista percorrer o corredor iluminado, a música de tom misterioso, a sequência "arrastada", de planos relativamente longos e a imagem da gilete que é constantemente desfocada, são os elementos que estabelecem esta sensação de dúvida, de insegurança, de indefinição. Quando o personagem está nu, em posição fetal, na beira do mar, a imagem por vezes fora de foco sugere uma espécie de comunhão de sua figura com as pedras. A agitação da câmera, bem acentuada em algumas cenas, é outro elemento de extrema importância para compor a atmosfera de angústia que o filme quer proporcionar. Este recurso está presente nos momentos de êxtase do filme, mais claramente na cena da conversa entre os dois personagens no cais, que precede o final.

Inserido no contexto do ano de 1968, o filme Novelo responde à renovação estética ocorrida na capital e discutida anteriormente neste artigo. Ao abandono do figurativo nas artes plásticas, segue-se o abandono da narrativa linear, no cinema. Os enquadramentos fechados, a irregularidade na narrativa, com cortes bruscos na sequência e a presença de cenas simbolicamente complexas, remetem às escolas de cinema vanguardistas, como o cinema de montagem russo, o cinema expressionista alemão e o cinema surrealista. Os temas do existencialismo, a cidade como cenário (predominância de cenas externas) e a "câmera na mão", têm o espírito da Nouvelle Vague e do Cinema Novo. A inquietude do protagonista e sua insatisfação diante da configuração social têm relação direta com o ambiente político da Ditadura Militar. O muro pichado com a frase "Nosso protesto não morreu", a questão da pobreza e a crítica à fuga tipicamente burguesa da esmola, são temas que relacionam o filme à trajetória do cinema latino-americano do período, sob a temática da dependência econômica dos países subdesenvolvidos. 


\section{A Via Crucis}

Em A Via Crucis, o protagonista vive a tragédia bíblica no contexto do golpe civil-militar de 1964. A trilha sonora do compositor alemão Karlheinz Stockhausen provoca agitação e desconforto ao espectador, contribuindo para o clima inquietante e perturbador do filme, já incitado pela montagem desconexa e agitada. A metáfora da crucificação do indivíduo moderno, com alusões à tortura, é apresentada de forma cifrada e de narrativa irregular.

A montagem descontínua do filme é a sua principal característica de linguagem. Ela se sobrepõe à narrativa da trajetória do personagem para compor uma atmosfera de aprisionamento, que envolve o filme e levanta as questões-chave que a obra quer discutir. Acima da simples narração da trajetória do personagem que sofre a Via Crucis, o filme quer dizer que ele não é o único cuja liberdade está sendo destituída. A montagem atribui grande ênfase à simbologia dos planos e cenas. Estes, analisados separadamente, convergem para o mesmo foco, dividido em dois elementoschave: a questão da individualidade e do aprisionamento, ou perda de liberdade. As crianças brincando vistas por detrás das grades do parque; o rato na gaiola e o pato de figura indefesa; pessoas vistas de dentro dos ônibus urbanos, cuja imagem enfatiza o formato quadrado e simétrico das janelas, remetendo à ideia de uma prisão, montam uma sequência de planos que se identificam de maneira indireta à perda de liberdade e que, justapostos, acentuam e estabelecem esta relação, que se torna consistente. As cenas que enfatizam as portas que se fecham são também cenas que tratam da perda de liberdade, sob outro viés: o protagonista sobe correndo uma escada com uma grande porta ao fundo, que se fecha lentamente antes que ele chegue, impedindo a sua passagem; num grande prédio, com várias portas voltadas para a rua, uma mulher corre por elas tentando abri-las. Nestas cenas, os personagens não estão por trás de grades, mas a sua liberdade é comprometida por serem impedidos de entrar onde almejam, sua livre passagem é negada. Literalmente, as portas os trancam para fora dos espaços, e diante deste fato, sua aparente liberdade não serve a nada.

O recurso da contraluz, por sua vez, alia-se a outra questão apontada: a perda de individualidade. Ele já se insinua logo no início do filme, na cena da rua movimentada, no centro da cidade, mas surge, de fato, nas cenas relacionadas à representação do trabalho. Nestas, os personagens que procuram emprego sem sucesso são vistos como sombras, sem a definição de sua fisionomia. Numa serralheria, os funcionários, em um 
plano relativamente longo, executam seu trabalho também sem serem identificados, devido à contraluz. A individualidade é retirada dos personagens simbolicamente pelo uso da contraluz e de fato, pelas situações que representam nas cenas.

A sonoplastia de A Via Crucis é outro elemento determinante da linguagem. Além de ser totalmente irregular, ela ainda foi manipulada de acordo com a velocidade das cenas, sendo atrasada juntamente com as imagens em câmera lenta, ou cortada juntamente com os cortes dos planos, produzindo efeitos inusitados, quase sempre compostos por ruídos disformes, efeito que contribuiu definitivamente para compor o clima sombrio e perturbador que envolve o filme. A anti-harmonia da estrutura musical estabelece firmemente o propósito da obra, em sintonia com as outras características formais aqui apontadas, transmitindo desconforto, deslocamento, perturbação.

A câmera agitada, por fim, complementa as características formais já apontadas e está intencionalmente presente em dois momentos marcantes do filme. O primeiro, quando a mulher corre por fora de um grande prédio, composto por diversas portas, tentando abri-las. Na cena em que a câmera acompanha a personagem, correndo atrás dela, enquanto ela tenta abrir as portas, o efeito provocado pela agitação da câmera faz com que os limites do desenho das portas e do corpo da mulher se desloquem constantemente. Este efeito plástico representa bem uma sensação de desespero e descontrole, vividos pela protagonista da cena. O segundo momento marcado pela câmera agitada está na cena da tortura do personagem principal, em que ele aparece agonizando, em contraste com a câmera fixa dos planos que contemplam os rostos da população que o observa. A câmera agitada, somente ao retratar a sua agonia, representa bem a ideia de alheamento por parte da população, diante de sua condenação: enquanto seu mundo "desmorona", os outros o observam em planos estáveis. O auge da narrativa inicia-se na praia, quando o personagem principal é capturado pelos indivíduos vestidos com terno e gravata. Eles rasgam-lhe as roupas e cortam seus cabelos, levando-o de volta ao ambiente urbano, que desta vez, mostra-se mais caótico do que antes. Buzinas de carros, sirenes de polícia, câmera agitada, muitos cortes entre as cenas. A junção das cenas de pessoas em seus carros buzinando irritadas, sirenes de polícia e as imagens de rostos de habitantes da cidade é o que nos dá a entender que a tortura se passa numa rua movimentada. Todos os planos desta sequência são fechados: os rostos estão em close, somente as mãos na buzina e uma parte do corpo do motorista aparecem e a sirene também surge sozinha, num plano bem 
aproximado. Estes planos são intercalados aos da tortura do personagem, cuja expressão facial é enfatizada, agonizando de dor. Em contraste com a agitação, proporcionada pela intensidade das cenas e pelos vários cortes, os planos parecem estar em câmera-lenta, o que atribui certa dramaticidade à sequência. Este momento, portanto, é o momento decisivo do filme, o auge da narração, para onde as significações construídas ao longo da obra convergem. O personagem é torturado diante da população, ele sofre diretamente as consequências advindas de toda a construção simbólica presente nas cenas que compõem o filme. Os elementos da linguagem visual atribuem uma série de características ao meio social e urbano, com o intuito de representá-lo simbolicamente como aprisionador.

\section{Olaria}

O documentário Olaria se constrói plasticamente a partir da união de duas narrativas: a visual (da montagem das imagens) e a sonora (da montagem da fala do Sr. Ricardo). O objetivo do filme foi o de registrar o trabalho artesanal da olaria, em vias de se perder. A abordagem estética e conceitual da obra, ao dar voz ao Sr. Ricardo como único narrador, sobrepõe a vivência do oleiro a qualquer teoria histórica ou sociológica. ${ }^{23}$ Sua fala está dessincronizada com a imagem, devido à falta de experiência no uso das câmeras. ${ }^{24}$ Diante disso, foi assumida a falta de sincronia, mesmo quando o Sr. Ricardo aparece falando.

O oleiro é protagonista do documentário, seu discurso é legitimado pelo papel principal na narração. Ele fala do recente processo de industrialização, do crescimento da cidade de Florianópolis e região metropolitana e da mudança de sua situação econômica. As imagens, por sua vez, propõem um olhar contemplativo sobre o trabalho dos oleiros, documentando as suas especificidades, os detalhes da produção artesanal. A câmera não realiza movimentos bruscos e não há justaposições frenéticas de planos, tudo é mostrado com calma, da mesma forma como é realizada a

\footnotetext{
${ }^{23} \mathrm{Na}$ época era comum a utilização do modelo de documentário chamado de sociológico, que define generalizações sobre a situação social discutida, encaixando a tese proposta em um modelo fechado, sustentado por estatísticas. Fonte: BERNARDET, Jean-Claude. Cineastas e imagens do povo. São Paulo: Companhia das Letras, 2003.

${ }^{24}$ Informações retiradas do depoimento de Nelson dos Santos: MACHADO, Nelson dos Santos. Depoimento, maio de 2005, Córrego Grande, Florianópolis. Entrevistadoras: Sissi Valente Pereira e Gláucia Dias da Costa. Acervo do Laboratório de Pesquisa em Imagem e Som - LAPIS, UFSC.
} 
feitura do jarro de barro, com cuidado. Os enquadramentos são fechados, em sua maioria, para dar ênfase aos detalhes da manufatura. Há também diversos closes nos rostos dos trabalhadores. As cenas externas têm planos mais abertos, que mostram o forno da olaria, o local onde amassam a argila (com a ajuda de um cavalo), o quintal onde colocam os vasos para secar. Um panorama da casa, ao longe, com o mar ao fundo, inaugura o espaço ao espectador, no início do filme.

Enquanto a montagem das cenas transmite um ritmo lento e constante, que se inspira no cotidiano dos trabalhadores da olaria, contraditoriamente, a narração do Sr. Ricardo prevê o fim iminente de seu trabalho. O foco de sua narrativa está na consciência da perda de valor social de sua função como artesão. O Sr. Ricardo, como um "personagem" real, vive também as consequências do processo histórico, da mesma forma que os protagonistas dos dois filmes de ficção. Sua trajetória de vida é condicionada por circunstâncias que estão fora de seu controle. O filme deixa isto claro por meio de sua narrativa e escolhas estéticas. Temos a impressão de que a montagem das imagens quer simbolicamente apreender e eternizar a beleza do processo artesanal da feitura do jarro, enquanto a montagem sonora representaria a "dureza" da realidade, que não pode ser modificada. O filme discute, portanto, a transformação das relações sociais diante da intensificação do modelo capitalista e critica este modelo, de forma direta, por meio do depoimento do oleiro, e de forma indireta, na exaltação do trabalho artesanal da olaria, presente na montagem visual.

Nelson dos Santos comenta, em depoimento, o sentimento de inconformidade existente nas duas obras de sua autoria, A Via Crucis e Olaria:

Eu compartilho dessa ideia da problematização nesse sentido positivo, no sentido de aproveitar aquilo que nós temos de grandeza como espécie animal, que é a nossa possibilidade de crítica, de reflexão, talvez de não conformidade de como as coisas são colocadas, ou se colocam pra nós. Então, tanto o A Via Crucis quanto o Olaria tangenciam essa inconformidade, esse mal estar diante do que os dois contextos se realizam. ${ }^{25}$

${ }^{25}$ MACHADO, Nelson dos Santos. Depoimento, maio de 2005, op.cit. 
Em Novelo e em A Via Crucis é visível uma mudança de perspectiva em relação à representação da cidade, que tira o foco dos elementos que caracterizavam Florianópolis como tal. Em contraste com o filme $O$ Preço da Ilusão, ${ }^{26}$ nestes filmes os casarios antigos, antes identificados à identidade da cidade, se transformam em elementos de uma paisagem urbana caótica. Em Novelo, a ponte Hercílio Luz, elemento importante na narrativa de $O$ Preço da Ilusão, se torna mera ligação entre a ilha e o continente. Sua estrutura metálica é enfatizada de perto, filmada de dentro, transformando significativamente o efeito visual causado por sua aparição: no filme ela aparece como um estorvo, um corte no fluxo de ação do personagem, devido ao engarrafamento enfrentado por ele, e mais um elemento que o perturba dentro da atmosfera urbana. Estas e outras características já apontadas identificam estes filmes como interessantes fontes para o estudo do contexto da cidade e das artes locais do período, que se distanciam bastante das representações que conhecemos atualmente.

Há um traço característico nos três filmes, que os identifica ao sentimento de inconformidade. Em Novelo, o personagem quer se destituir dos valores burgueses, se desvincular de um conceito de sociedade que para ele não se legitima. Em A Via Crucis, o protagonista se vê acuado por um regime de poder que, para ele, anula sua individualidade e sua autonomia social. E esta anulação não é somente moral, é também física, aparecendo na forma de perseguição, tortura e morte. Em Olaria, que não é uma ficção, o "personagem" de Sr. Ricardo compartilha do mesmo sentimento dos outros personagens fictícios e também se vê fora do sistema de relações sociais e econômicas vigente. Os sentimentos dos três personagens são bem claros: explicitam a inconformidade, a indignação diante da situação na qual estão inseridos. Nos três filmes há um movimento forte e claro de impulso para a transformação. Mesmo que esta não tenha a possibilidade de se concretizar, existe o impulso, a não conformidade com o que está apresentado, a consciência de que aquela não é a sociedade que se quer. Os três filmes lidam com situações extremas, que são desencadeadas devido ao posicionamento, por parte dos personagens, diante do meio social.

Artigo enviado em abril de 2011; aprovado em novembro de 2011.

${ }^{26}$ Ver sinopse na nota de rodapé n.3. 